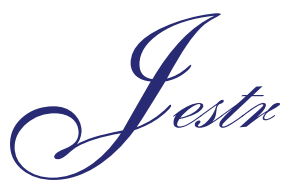

\title{
Analysis of air-conditioning and drying processes using spreadsheet add-in for psychrometric data
}

\author{
C.O.C. Oko* and E.O. Diemuodeke
}

Department of Mechanical Engineering, University of Port Harcourt, P.M.B 5323 Port Harcourt, Nigeria.

Received 6 October 2009; Accepted 23 December 2009

\begin{abstract}
A spreadsheet add-in for the psychrometric data at any barometric pressure and in the air-conditioning and drying temperature ranges was developed using appropriate correlations. It was then used to simulate and analyse air-conditioning and drying processes in the Microsoft Excel environment by exploiting its spreadsheet and graphic potentials. The package allows one to determine the properties of humid air at any desired state, and to simulate and analyse air-conditioning as well as drying processes. This, as a teaching tool, evokes the intellectual curiosity of students and enhances their interest and ability in the thermodynamics of humid-air processes.
\end{abstract}

Keywords: Psychrometry, air-conditioning, drying, spreadsheet add-in, Microsoft Excel.

\section{Introduction}

The properties of humid air are very important in air-conditioning and drying process analysis and system design. The property data are usually provided as tables and charts of properties. But, reading the psychrometric charts is strenuous, time consuming and always prone to errors, and the use of property tables frequently requires interpolation between the tabulated data, which is also manual and time consuming activity. However, the proliferation of computer technology in contemporary engineering practice ensures greater speed and accuracy, and thus should limit or even eliminate the use of property charts and tables in engineering analysis. The present trend in engineering practice is, therefore, towards the development of computer packages that are capable of automatic generation of the values of the desired thermodynamic properties, and thus, facilitating their use in engineering analysis [1].

Many computer software packages are now available for engineering analysis, which have the facility for providing the thermodynamic properties of working fluids $[1,2]$. But these packages are not available in most computers; they must be bought and installed; they cannot be modified by their users, say, to account for varying barometric pressure; special training is usually required for their users; and internet connectivity may be necessary. But these shortcomings can be overcome if computer packages that are easy to develop, modify and exploit by users are available. The Microsoft (MS) Excel offers a suitable environment for the development of such packages $[3,4,5]$.

* E-mail address: chimaoko@yahoo.com

ISSN: 1791-2377 (C) 2010 Kavala Institute of Technology. All rights reserved.
Therefore, it is possible to develop computer procedures in Visual Basic for Applications (VBA) for generating the psychrometric data as spreadsheet add-ins. Such a procedure would then be used in the MS Excel environment for the simulation and analysis of air-conditioning and drying processes in an interactive fashion and in a manner that fully exploits the spreadsheet and graphic potentials of MS Excel. Such tool would assist the design engineer in his work, especially when incorporated into a larger plant design software. It would also be tool an easily affordable tool for the effective teaching of air-conditioning and drying engineering principles to students of mechanical and chemical engineering. The use of the MS Excel environment for enhancing the learning process in engineering is not new $[6,7,8,9]$. Our experience has also shown that students exhibit greater interest, commitment and ability in using the spreadsheet for problem solving, especially when graphical output is involved, than in the traditional approach.

This paper, therefore, presents a spreadsheet add-in for the psychrometric data for any barometric pressure and in the dry bulb temperature range of 0 to $550\left({ }^{\circ} \mathrm{C}\right)$, and uses it to illustrate the interactive determination of the state properties of humid air, and simulation and analysis of air-conditioning and drying processes.

\section{Governing Equations}

Following the works of $[10,11,12]$, the basic psychrometric properties are related as follows: 
Specific humidity $(g)$ :

$g=0.622 \frac{P_{w v}}{\left(P_{b}-P_{w v}\right)}$

where $P_{b}$ and $P_{w v}$ are the barometric pressure and partial pressure of the water vapour, respectively.

If the temperature of humid air $(t)$ is higher than the temperature of saturation $\left(t_{s}\right)$ of water vapour $(w v)$ at the dry air $(d a)$ pressure $\left(P_{d . a}\right)$, that is, $t>t_{s}$, then $P_{w v}=P_{d a}$ and

$g=0.622 \frac{R H}{(1-R H)}$

where $R H$ is the relative humidity of the air, given as

$$
R H=\frac{P_{w v}}{P_{s}} 100
$$

where $P_{s}$ is the saturation pressure of the water vapour.

Enthalpy of Moist Air $(h)$ :

$h=c_{p_{d a}} t+g\left(2501+c_{p_{w v}} t\right)$

where $t, c_{p_{d a}}$, and $c_{p_{w v}}$ are the dry bulb temperature, specific heat capacity of the dry air, and specific heat capacity of the water vapour, respectively.

The average specific heat capacities are given, respectively for air-conditioning and drying processes as $c_{p_{d a}}=1.005(\mathrm{~kJ} / \mathrm{kgK})$ and $c_{p_{w v}}=1.88(\mathrm{~kJ} / \mathrm{kgK})$, and $c_{p_{d a}}=1.01(\mathrm{~kJ} / \mathrm{kgK})$ and $c_{p_{w v}}=1.97$ $(\mathrm{kJ} / \mathrm{kgK})$.

Wet Bulb Temperature $\left(t_{w b}\right)$ and Thermodynamic Wet Bulb Temperature $\left(t^{*}\right)$ :

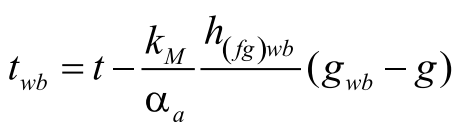

and

$t^{*}=t-\frac{h_{f g}^{*}}{c_{p}}\left(g^{*}-g\right)$

where

$c_{p}=c_{p_{d . a}}+g c_{p_{w . v}}$

$L e=0.945$ is the Lewis number for humid air, in which case $t_{w b} \approx t^{*} ; \alpha_{\alpha}\left[\mathrm{W} / \mathrm{m}^{2} K\right], k_{M}\left[\mathrm{~kg}_{w . v} / \mathrm{m}^{2} \mathrm{~s}\right]$, and $c_{p}\left[\mathrm{~kJ} / \mathrm{kg}_{\text {d.a }} K\right]$ are the heat transfer coefficient of the air film around the wetted surface, the mass transfer coefficient based on the specific humidity $(\mathrm{g})$ and the humid specific heat, respectively; $h_{(g) w b}$ and $g_{w v}$ are the specific latent enthalpy and specific humidity at the wet bulb temperature, respectively; and $R_{d a}=0.2873[\mathrm{~kJ} / \mathrm{kgK}]$ is the dry air gas constant; the superscript "**" denotes adiabatic saturation properties and the indices " $f g$ " and " $w b$ " denote latent conditions and wet bulb temperature, respectively.
The Carrier's equation for the partial pressure of the water vapour, $P_{w v}$, is given as

$P_{w v}=P_{(s) w b}-\frac{1.8\left(P_{w v}-P_{(s) w b}\right)\left(t-t_{w b}\right)}{2800-1.3(1.8 t+32)}$

where $P_{(s) w b}[\mathrm{kPa}]$ is the saturation pressure at the wet bulb temperature.

Specific volume $(v)$ :

$v=\frac{R_{d . a} T}{P_{b}-P_{w . v}}$

where $T[\mathrm{~K}]$ is the absolute temperature of humid air, $T=273+t$ ; $t$ is temperature in degree celsius.

The humid air analysis is carried out using the following algorithm:

start

input data:

i. obtain the prevailing barometric pressure;

ii. obtain the desired (unknown) property (specific enthalpy, dry bulb temperature, wet bulb temperature, specific volume, specific humidity, relative humidity or dew point temperature);

iii. obtain two known properties and their values; compute (using the relevant relationships for the psychrometric properties) the specific humid volume, specific enthalpy, specific humidity, dry-bulb, wet-bulb or dew-point temperature;

output the desired data (property name and numerical value); use the output for process simulation and analysis, if desired;

plot psychrometric charts, if desired; stop.

The software was developed in MS Excel Visual Basic for Application Integrated Development Environment (Excel-VBA IDE) as an Excel add-in, called Psychrometric_data, using all the relevant correlations for the thermodynamic analysis of humid air, given in the governing equations, and following the computational algorithm. Some of the procedures are iterative with an error bound of $0.01 \%$. The interface retrieves and supplies information on any of the humid air properties. A command button control on the Excel form is used to run the macro that implements a particular function.

After a successful installation of the Excel add-in, the Psychrometric_data menu is seen on the standard menu bar. By clicking on the Start button of the Psychrometric_data menu, the window shown in Figure 1 appears. Select the process type (Drying or Air Conditioning) by clicking on the relevant OptionButton. If the barometric pressure is different from the standard, $\mathrm{P}_{\mathrm{b}}=101.325$ [kPa], check the No box, and enter the prevailing barometric pressure in the TextBox provided. Select the unknown property from the ComboBox captioned Unknown Property. In the ComboBox captioned Function, $\wp(. ., \ldots)$, select the known properties. Key in 
the numerical values of the known properties into the TextBoxes in the Frame captioned Input the known data. By clicking on the CommandButton captioned Read, the Psychrometric_data uses the relevant correlations to obtain the numerical value of the desired property, which is displayed in the Output Data Frame and is also automatically transferred to a pre-selected cell in the worksheet for further use. The process continues for another state by clicking on the Continue drop menu of the Psychrometric_data menu.

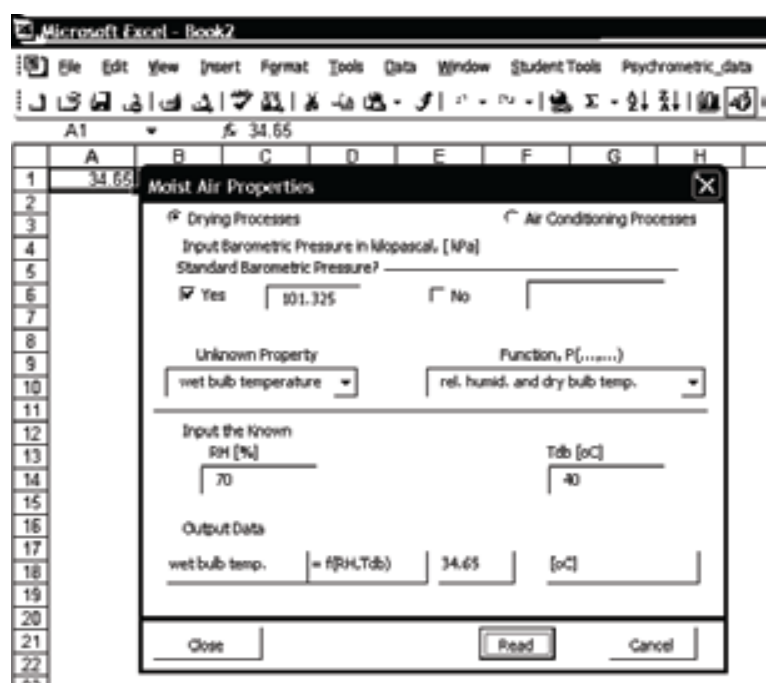

Figure 1. The add-in (Psychrometric_data) window.

\section{Results and Discussion}

As an Excel add-in, Psychrometric_data is designed to aid students as well as practicing air conditioning or drying plant engineers in their design/performance analysis by automatically providing the desired property data in the environment, for the relevant spreadsheet analysis. To illustrate how this is achieved, we consider the following problems:

1. A room for process work is maintained at $20^{\circ} \mathrm{C}$ dry bulb (db) temperature and $25 \%$ relative humidity $(\mathrm{RH})$. The outside air is at $40^{\circ} \mathrm{C} \mathrm{db}$ and $25^{\circ} \mathrm{C}$ wet buld (wb) temperature. Twelve cubic metre per minute $(\mathrm{cmm})$ of fresh air is mixed with a part of the recirculated air, and another passed over the adsorption dehumidifier. It is then mixed with another part of the recirculated air, and sensibly cooled in the cooler before being supplied to the room at $14^{\circ} \mathrm{C}$. The room sensi-

\begin{tabular}{|c|c|}
\hline $\begin{array}{c}\text { inlet humidity ratio, } \mathrm{g}_{1} \times 10^{3} \\
{\left[\mathrm{~g} / \mathrm{kg}_{\mathrm{d} . \mathrm{a}}\right]}\end{array}$ & $\begin{array}{c}\text { exit humidity ratio, } \mathrm{g}_{2} \times 10^{3} \\
{\left[\mathrm{~g} / \mathrm{kg}_{\mathrm{d} . \mathrm{a}}\right]}\end{array}$ \\
\hline 2.86 & 0.43 \\
\hline 4.29 & 0.57 \\
\hline 5.70 & 1.00 \\
\hline 7.15 & 1.57 \\
\hline 8.57 & 2.15 \\
\hline 10.00 & 2.86 \\
\hline 11.43 & 3.57 \\
\hline 12.86 & 4.57 \\
\hline 14.29 & 5.23 \\
\hline & \\
\hline
\end{tabular}

ble and latent heat gains are 6 and $0.8 \mathrm{~kW}$, respectively. The performance of the dehumidifier (adsorbent material) is characterized by the inlet and exit humidity ratios of the air flowing through it, which are tabulated below. Assume the heat of adsorption of moisture to be $390 \mathrm{~kJ} / \mathrm{kg}_{\mathrm{w} . \mathrm{v}}$ Determine the volume flow rate of the air through the dehumidifier and the heat transfer rate in the cooler [10].

Solution: (The following solution steps are carried out on the MS Excel worksheet)

Input data: (the given data in the problem)

\begin{tabular}{ccccc}
\hline S/No & Quantity & Symbol & Units & Value \\
\hline 1 & dry bulb temperature of & $\mathrm{t}_{\mathrm{dbi}}$ & ${ }^{\circ} \mathrm{C}$ & 20 \\
2 & $\begin{array}{c}\text { room } \\
\text { relative humidity of } \\
\text { room }\end{array}$ & $\mathrm{RH}_{\mathrm{i}}$ & $\%$ & 25 \\
3 & $\begin{array}{c}\text { dry bulb temperature of } \\
\text { outside air }\end{array}$ & $\mathrm{t}_{\mathrm{dbo}}$ & ${ }^{\circ} \mathrm{C}$ & 40 \\
4 & $\begin{array}{c}\text { wet bulb temperature of } \\
\text { outside air }\end{array}$ & $\mathrm{t}_{\mathrm{wbo}}$ & ${ }^{\circ} \mathrm{C}$ & 25 \\
5 & $\begin{array}{c}\text { volume flow rate of } \\
\text { outside air }\end{array}$ & $\mathrm{V}_{\mathrm{o}}$ & $\mathrm{m}^{3} / \mathrm{s}$ & 0.2 \\
6 & $\begin{array}{c}\text { dry bulb temp. of air } \\
\text { leaving the cooler }\end{array}$ & $\mathrm{t}_{\mathrm{dbs}}$ & ${ }^{\circ} \mathrm{C}$ & 14 \\
7 & room sensible heat & $\mathrm{Q}_{\mathrm{RS}}$ & $\mathrm{kW}$ & 6.0 \\
8 & room latent heat & $\mathrm{Q}_{\mathrm{RL}}$ & $\mathrm{kW}$ & 0.8 \\
\hline
\end{tabular}

\section{Sketches/Diagrams:}

(Figure 2 shows the plant flow sheet and process diagram).
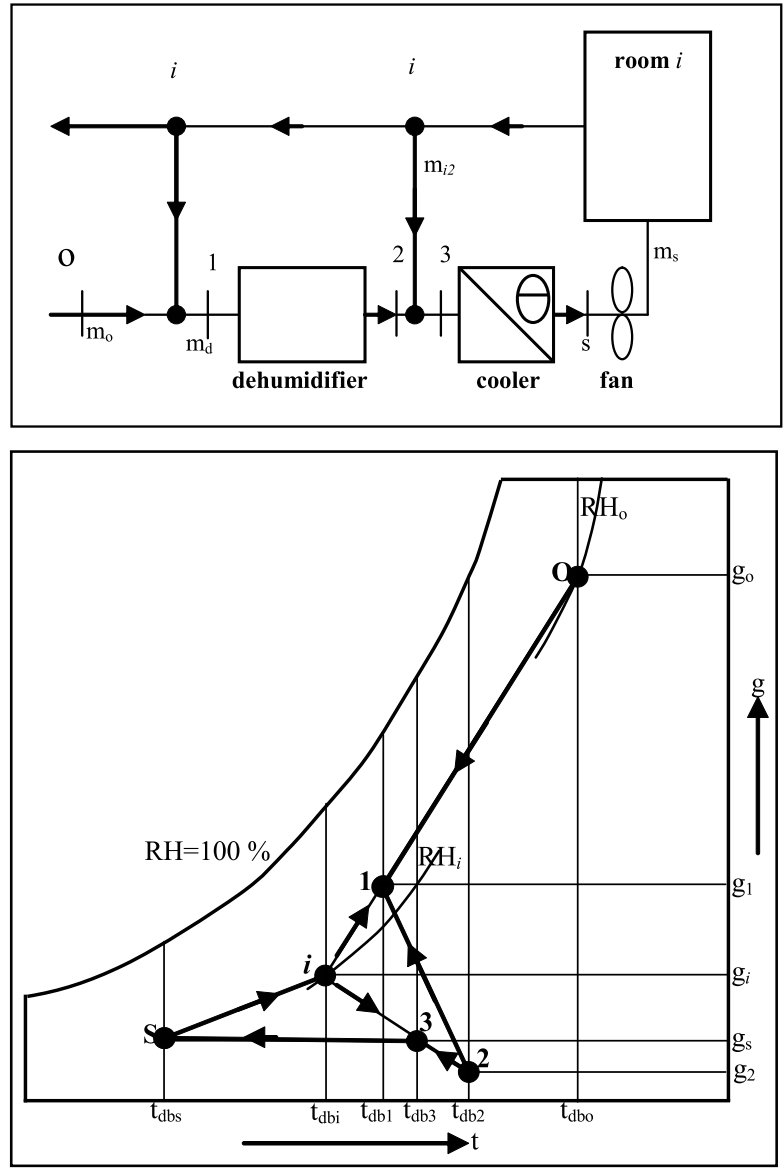

Figure 2. The air-conditioning plant and processes. 
(psychrometric data obtained using the add-in, $\wp(\ldots, \ldots)$

\begin{tabular}{|c|c|c|c|c|c|}
\hline S/No & Quantity & Symbol & Units & Function & Value \\
\hline 1 & $\begin{array}{l}\text { wet bulb tempera- } \\
\text { ture of room }\end{array}$ & $\mathrm{t}_{\mathrm{wbi}}$ & ${ }^{\circ} \mathrm{C}$ & $\wp\left(\mathrm{t}_{\mathrm{dbi}}, \mathrm{RH}_{\mathrm{i}}\right)$ & 11.210 \\
\hline 2 & $\begin{array}{l}\text { specific enthalpy } \\
\text { of outside air }\end{array}$ & $\mathrm{h}_{\mathrm{o}}$ & $\mathrm{kJ} / \mathrm{kg}_{\text {d.a }}$ & $\wp\left(\mathrm{t}_{\mathrm{dbo}}, \mathrm{t}_{\mathrm{wbo}}\right)$ & 75.760 \\
\hline 3 & $\begin{array}{l}\text { specific enthalpy } \\
\text { of room air }\end{array}$ & $\mathrm{h}_{\mathrm{i}}$ & $\mathrm{kJ} / \mathrm{kg}_{\text {d.a }}$ & $\wp\left(\mathrm{t}_{\mathrm{dbi}}, \mathrm{RH}_{\mathrm{i}}\right)$ & 29.010 \\
\hline 4 & $\begin{array}{l}\text { specific humidity } \\
\text { of outside air }\end{array}$ & $\mathrm{g}_{\mathrm{o}}$ & $\mathrm{kg}_{w . n} / \mathrm{kg}_{d . a}$ & $\wp\left(\mathrm{t}_{\mathrm{dbo}}, \mathrm{t}_{\mathrm{wbo}}\right)$ & 0.014 \\
\hline 5 & $\begin{array}{l}\text { specific humidity } \\
\text { of room air }\end{array}$ & $\mathrm{g}_{\mathrm{i}}$ & $\mathrm{kg}_{w, n} / \mathrm{kg}_{d \cdot a}$ & $\wp\left(\mathrm{t}_{\mathrm{dbi}}, \mathrm{RH}_{\mathrm{i}}\right)$ & 0.003 \\
\hline 6 & $\begin{array}{l}\text { specific volume of } \\
\text { outside air }\end{array}$ & $\mathrm{v}_{\mathrm{o}}$ & $\mathrm{m}^{3} / \mathrm{kg}_{d . a}$ & $\wp\left(\mathrm{t}_{\mathrm{dbo}}, \mathrm{t}_{\mathrm{wbo}}\right)$ & 0.907 \\
\hline 7 & $\begin{array}{l}\text { relative humidity } \\
\text { of outside air }\end{array}$ & $\mathrm{RH}_{\mathrm{o}}$ & $\%$ & $\wp\left(\mathrm{t}_{\mathrm{dbo}}, \mathrm{t}_{\mathrm{wbo}}\right)$ & 29.570 \\
\hline 8 & $\begin{array}{l}\text { specific volume of } \\
\text { room air }\end{array}$ & $\mathrm{v}_{\mathrm{i}}$ & $\mathrm{m}^{3} / \mathrm{kg}_{d . a}$ & $\wp\left(\mathrm{t}_{\mathrm{dbi}}, \mathrm{RH}_{\mathrm{i}}\right)$ & 0.835 \\
\hline
\end{tabular}

\begin{tabular}{ccccr}
\hline Data read from literature: & & & \\
\hline 1 & $\begin{array}{c}\text { isobaric specific heat } \\
\text { capacity of air }\end{array}$ & $\mathrm{c}_{\mathrm{p}}$ & $\mathrm{kJ} / \mathrm{kg}$ & 1.024 \\
2 & $\begin{array}{c}\text { Specific heat of } \\
\text { vaporization }\end{array}$ & $\mathrm{h}_{\text {fgref }}$ & $\mathrm{kJ} / \mathrm{kg}$ & 2500 \\
3 & reference temperature & $\mathrm{t}_{\mathrm{ref}}$ & ${ }^{\circ} \mathrm{C}$ & 25 \\
4 & Reference density & $\rho_{\mathrm{ref}}$ & $\mathrm{kg} / \mathrm{m}^{3}$ & 1.2 \\
5 & heat of adsorption & $\mathrm{Q}_{\mathrm{a}}$ & $\mathrm{kW}$ & 390 \\
6 & Iteration error & $\varepsilon$ & - & 0.000005 \\
\hline
\end{tabular}

Computation: (provides answers the questions asked)

\begin{tabular}{|c|c|c|c|c|c|}
\hline S/No & Quantity & Symbol & Units & Function & Value \\
\hline 1 & mass flow rate of fresh air & $\mathrm{m}_{\mathrm{o}}$ & $\mathrm{kg} / \mathrm{s}$ & $\mathrm{m}_{\mathrm{o}}=\mathrm{V}_{\mathrm{o}} / \mathrm{v}_{\mathrm{o}}$ & 0.221 \\
\hline 2 & temperature rise of supply air in the room & $\Delta \mathrm{t}_{\mathrm{dbs}}$ & ${ }^{\circ} \mathrm{C}$ & $\Delta \mathrm{t}_{\mathrm{s}}=\mathrm{t}_{\mathrm{dbi}}-\mathrm{t}_{\mathrm{dbs}}$ & 6.000 \\
\hline 3 & sensible volumetric heat constant & $\mathrm{K}_{\mathrm{S}}$ & $\mathrm{kJ} / \mathrm{m}^{3}$ & $\mathrm{~K}_{\mathrm{s}}=\rho_{\mathrm{ref}} \mathrm{c}_{\mathrm{p}}\left(273+\mathrm{t}_{\mathrm{ref}}\right)$ & 366 \\
\hline 4 & volume flow rate of supply air & $\mathrm{V}_{\mathrm{s}}$ & $\mathrm{m}^{3} / \mathrm{s}$ & $\mathrm{V}_{\mathrm{s}}=\mathrm{Q}_{\mathrm{RS}}\left(\mathrm{t}_{\mathrm{dbs}}+273\right) /\left(\mathrm{K}_{\mathrm{S}} \Delta \mathrm{t}_{\mathrm{dbs}}\right)$ & 0.784 \\
\hline 5 & Latent volumetric heat constant & $\mathrm{K}_{\mathrm{L}}$ & $\mathrm{kJ} / \mathrm{m}^{3}$ & $\mathrm{~K}_{\mathrm{L}}=\rho_{\mathrm{ref}} \mathrm{h}_{\mathrm{fgref}}\left(273+\mathrm{t}_{\mathrm{ref}}\right)$ & 894000 \\
\hline 6 & specific humidity of supply air & $g_{s}$ & $\mathrm{~kg}_{w . v} / \mathrm{kg}_{d . a}$ & $\mathrm{~g}_{\mathrm{s}}=\mathrm{g}_{\mathrm{i}}-\mathrm{Q}_{\mathrm{RL}}\left(\mathrm{t}_{\mathrm{dbs}}+273\right) /\left(\mathrm{K}_{\mathrm{L}} \mathrm{V}_{\mathrm{s}}\right)$ & 0.003 \\
\hline 7 & heat taken by the supply air per unit mass & $\mathrm{q}_{\mathrm{s}}$ & $\mathrm{kJ} / \mathrm{kg}$ & $\mathrm{q}_{\mathrm{s}}=\mathrm{c}_{\mathrm{p}} \Delta \mathrm{t}_{\mathrm{dbs}}$ & 6.144 \\
\hline 8 & mass flow rate of fresh air & $\mathrm{m}_{\mathrm{s}}$ & $\mathrm{kg} / \mathrm{s}$ & $\mathrm{m}_{\mathrm{s}}=\mathrm{Q}_{\mathrm{RS}} / \mathrm{q}_{\mathrm{s}}$ & 0.977 \\
\hline 9 & mass flow rate of the recirculated air & $\mathrm{m}_{\mathrm{i}}$ & $\mathrm{kg} / \mathrm{s}$ & $\mathrm{m}_{\mathrm{i}}=\mathrm{m}_{\mathrm{s}}-\mathrm{m}_{\mathrm{o}}$ & 0.756 \\
\hline 10 & specific humidity of air at the inlet of the dehumidifier & $\mathrm{g}_{1}$ & $\mathrm{~kg}_{w . v} / \mathrm{kg}_{\text {d.a }}$ & $\mathrm{g}_{1}=\varphi\left(\mathrm{g}_{1}, \varepsilon\right)^{*}$ & $0.010^{*}$ \\
\hline 11 & mass flow rate of recirculated air mixing before the cooler & $\mathrm{m}_{\mathrm{i} 2}$ & $\mathrm{~kg} / \mathrm{s}$ & $\mathrm{m}_{\mathrm{i} 2}=\mathrm{m}_{\mathrm{i}}-\mathrm{m}_{\mathrm{i} 1}$ & 0.614 \\
\hline 12 & mass flow rate of air entering the dehumidifier & $\mathrm{m}_{\mathrm{d}}$ & $\mathrm{kg} / \mathrm{s}$ & $\mathrm{m}_{\mathrm{d}}=\mathrm{m}_{\mathrm{s}}-\mathrm{m}_{\mathrm{i} 2}$ & 0.363 \\
\hline 13 & recirculation/fresh air mass mixing ratio & $\gamma_{\mathrm{il}, \mathrm{o}}$ & - & $\gamma_{\mathrm{il}, \mathrm{o}}=\mathrm{m}_{\mathrm{il}} / \mathrm{m}_{\mathrm{o}}$ & 0.644 \\
\hline 14 & temperature of air entering the dehumidifier & $\mathrm{t}_{\mathrm{db} 1}$ & ${ }^{\circ} \mathrm{C}$ & $\mathrm{t}_{\mathrm{db} 1}=\left(\mathrm{t}_{\mathrm{dbo}}+\zeta_{\mathrm{il}, \mathrm{o}} \mathrm{t}_{\mathrm{dbi}}\right) /\left(1+\zeta_{\mathrm{il}, \mathrm{o}}\right)$ & 32.165 \\
\hline 15 & specific volume of air entering the dehumidifier & $\mathrm{v}_{1}$ & $\mathrm{~m}^{3} / \mathrm{kg}_{d . a}$ & $\wp\left(\mathrm{t}_{\mathrm{db} 1}, \mathrm{~g}_{1}\right)$ & 0.878 \\
\hline 16 & volume flow rate of air through the dehumidifier & $\mathrm{V}_{\mathrm{d}}$ & $\mathrm{m}^{3} / \mathrm{s}$ & $\mathrm{V}_{\mathrm{d}}=\mathrm{m}_{\mathrm{d}} \mathrm{V}_{\mathrm{l}}$ & 0.318 \\
\hline 17 & specific humidity of air at the exit of the dehumidifier & $\mathrm{g}_{2}$ & $\mathrm{~kg}_{w . v} / \mathrm{kg}_{d . a}$ & $\mathrm{~g}_{2}=-0.1273 \mathrm{~g}_{1}+0.00382$ & $0.003^{*}$ \\
\hline 18 & mass flow rate of recirculated air before the dehumidifier & $\mathrm{m}_{\mathrm{il}}$ & $\mathrm{kg} / \mathrm{s}$ & $\mathrm{m}_{i l}=\mathrm{m}_{\mathrm{o}}\left(\mathrm{g}_{1}-\mathrm{g}_{\mathrm{o}}\right) /\left(\mathrm{g}_{\mathrm{i}}-\mathrm{g}_{1}\right)$ & 0.142 \\
\hline 19 & specific humidity drop in the dehumidifier & $\Delta_{\mathrm{gd}}$ & $\mathrm{kg}_{w .} / \mathrm{kg}_{d . a}$ & $\Delta \mathrm{g}_{\mathrm{d}}=\mathrm{g}_{2}-\mathrm{g}_{1}$ & -0.007 \\
\hline 20 & heat transfer rate due to condensation in dehumidifier & $Q_{\text {cond }}$ & $\mathrm{kW}$ & $\mathrm{Q}_{\mathrm{cond}}=2500 \mathrm{~m}_{\mathrm{d}} \mathrm{I} \Delta \mathrm{g}_{\mathrm{d}} \mathrm{I}$ & 6.345 \\
\hline 21 & heat transfer rate due to adsorption of moisture in the dehumidifier & Qads & $\mathrm{kW}$ & $\mathrm{Q}_{\mathrm{ads}}=\mathrm{Q}_{\mathrm{a}} \mathrm{m}_{\mathrm{d}} \mathrm{I} \Delta \mathrm{g}_{\mathrm{d}} \mathrm{I}$ & 0.990 \\
\hline 22 & total heat transfer rate in the dehumidifier & $\mathrm{Q}_{\mathrm{d}}$ & $\mathrm{kW}$ & $\mathrm{Q}_{\mathrm{d}}=\mathrm{Q}_{\text {cond }}+\mathrm{Q}_{\mathrm{ads}}$ & 7.335 \\
\hline 23 & temperature rise in the dehumidifier & $\Delta \mathrm{t}_{\mathrm{dbd}}$ & ${ }^{\circ} \mathrm{C}$ & $\Delta \mathrm{t}_{\mathrm{dbd}}=\mathrm{Q}_{\mathrm{d}} /\left(\mathrm{m}_{\mathrm{d}} \mathrm{c}_{\mathrm{p}}\right)$ & 19.756 \\
\hline 24 & temperature of air exiting the dehumidifier & $\mathrm{t}_{\mathrm{db} 2}$ & ${ }^{\circ} \mathrm{C}$ & $\mathrm{t}_{\mathrm{db} 2}=\mathrm{t}_{\mathrm{db} 1}+\Delta \mathrm{t}_{\mathrm{dbd}}$ & 51.920 \\
\hline 25 & dehumidifier/recirculation air mass mixing ratio & $\gamma_{\mathrm{i} 2,2}$ & - & $\gamma_{\mathrm{i} 2,2}=\mathrm{m}_{\mathrm{i} 2} / \mathrm{m}_{\mathrm{d}}$ & 1.693 \\
\hline 26 & temperature of air entering the cooler & $\mathrm{t}_{\mathrm{db} 3}$ & ${ }^{\circ} \mathrm{C}$ & $\mathrm{t}_{\mathrm{db} 3}=\left(\mathrm{t}_{\mathrm{db} 2}+\gamma_{\mathrm{i} 2,2} \mathrm{t}_{\mathrm{dbi}}\right) /\left(1+\gamma_{\mathrm{i} 2,2}\right)$ & 31.851 \\
\hline 27 & specific enthalpy of air entering the cooler & $\mathrm{h}_{3}$ & $\mathrm{~kJ} / \mathrm{kg}_{\text {d.a }}$ & $\wp\left(\mathrm{t}_{\mathrm{db} 3}, \mathrm{~g}_{\mathrm{s}}\right)$ & 41.260 \\
\hline 28 & specific enthalpy of the supply air & $\mathrm{h}_{\mathrm{s}}$ & $\mathrm{kJ} / \mathrm{kg}_{d \cdot a}$ & $\wp\left(\mathrm{t}_{\mathrm{dbs}}, \mathrm{g}_{\mathrm{s}}\right)$ & 22.120 \\
\hline 29 & heat transfer rate in the cooler & $Q_{c}$ & $\mathrm{~kW}$ & $\mathrm{Q}_{\mathrm{c}}=\mathrm{m}_{\mathrm{s}} \mathrm{Ih}_{\mathrm{s}}-\mathrm{h}_{3} \mathrm{I}$ & 18.691 \\
\hline
\end{tabular}

* $g_{l}=\frac{g_{i}-g_{o}}{g_{i}-\frac{\left(m_{s} g_{s}-m_{i} g_{i}\right)}{m_{i}}} g_{2}+\frac{g_{o}-\left(1 / m_{o}\right)\left(m_{s} g_{s}-m_{i} g_{i}\right)}{g_{i}-\left(1 / m_{o}\right)\left(m_{s} g_{s}-m_{i} g_{i}\right)} g_{i} \quad ;$ or, $g_{2}=-0.12732 g_{1}+0.00382=f\left(g_{1}\right)$.

By curve fitting the experimental data for the dehumidifier performance using MS Excel curve fitting tool, we obtain $g_{2}=20.928 g_{1}^{2}+0.08 g_{I}-7 \times 10^{-5}=\varphi\left(g_{I}\right)$, Figure 3. Equating the last two equations, $f\left(g_{l}\right)=\varphi\left(g_{l}\right)$, we get the iteration scheme, $g_{1, j+1}=-100.989 g_{1, j}^{2}+0.01877$. Setting $g_{l, 0}=0.00286$ and iterating in Excel environment, within an absolute error bound of $10^{-5}$, we obtain the values of $g_{l}$ and $g_{2}$ as $g_{l}=0.0097$ and $g_{2}=-0.1273 g_{l}+0.00382=0.0027\left(\mathrm{~kg}_{w} / \mathrm{kg}_{\mathrm{da}}\right)$. 


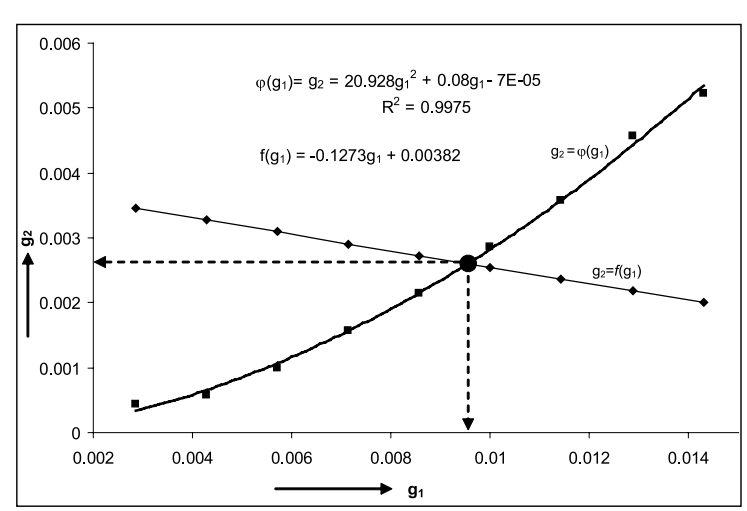

Figure 3. Curve fitting of the dehumidifier data and solution of the equation $f\left(g_{l}\right)=\varphi\left(g_{l}\right)$.

2. One tonne of some moist material is to be dried per hour from an initial moisture content of $u_{\text {in }}=50[\%]$ to a final moisture content of $\mathrm{u}_{\mathrm{fin}}=6[\%]$ (wet basis). The temperature and humidity of the outdoor air are $t_{0}=25[\%]$ and go $=0.0095$ $\left[\mathrm{kg}_{\text {w.v }} / \mathrm{kg}_{d . a}\right]$, respectively, and those of the air leaving the dryer (spent air) are $\mathrm{t}_{\mathrm{s}}=60\left[{ }^{\circ} \mathrm{C}\right]$ and $\mathrm{g}_{\mathrm{s}}=0.041\left[\mathrm{~kg}_{w . v} / \mathrm{kg}_{\text {d.a }}\right]$; where the subscripts " $w v$ " and " $d a$ " denote "water vapour" and "dry air", respectively. The drying of the moist material can be accomplished by any of the following three arrangements:

(a) The temperature of the outdoor air is raised in the heater before it enters the dryer; the humid air leaving the dryer (spent air) is exhausted into the atmosphere.

(b) The temperature of the outdoor air is raised to $100\left[{ }^{\circ} \mathrm{C}\right]$ in the heater; it enters the dryer and partially dries the moist material; it then enters the reheater, where its temperature is again raised to $100\left[{ }^{\circ} \mathrm{C}\right]$ before it is reintroduced into the dryer to complete the drying process; the spent air is then exhausted into the atmosphere.

(c) The outdoor air is mixed with 80 [\%] recirculated; it is then heated in the heater and introduced into the dryer to process the moist material; the spent air is exhausted into the atmosphere.

Determine the outdoor air flow rate through the dryer, and the power consumption (heat transfer rate) for each of the drying arrangements. Also compare the drying potentials of these arrangements [12].

Solution: (The following solution steps are carried out on the MS Excel worksheet)

Input data: (the given data in the problem)

\begin{tabular}{llccr}
\hline S/No & \multicolumn{1}{c}{ Quantity } & Symbol & Units & Value \\
\hline 1 & initial mass of moist material & $m_{m m}$ & $\mathrm{~kg} / \mathrm{s}$ & 0.278 \\
2 & initial moisture content of material & $\mathrm{u}_{\mathrm{in}}$ & - & 0.5 \\
3 & final moisture content of material & $\mathrm{u}_{\mathrm{fin}}$ & - & 0.06 \\
4 & temperature of air in case (b) heater & $\mathrm{t}_{\mathrm{dbb}}$ & ${ }^{\circ} \mathrm{C}$ & 100 \\
5 & fraction of recirculated air & $\kappa$ & - & 0.8 \\
6 & outside air dry bulb temperature & $\mathrm{t}_{\mathrm{dbo}}$ & ${ }^{\circ} \mathrm{C}$ & 25 \\
7 & outside air specific humidity & $\mathrm{g}_{\mathrm{o}}$ & $\mathrm{kg} / \mathrm{kg}_{\mathrm{d} . a}$ & 0.0095 \\
8 & spent air dry bulb temperature & $\mathrm{t}_{\mathrm{dbs}}$ & ${ }^{\circ} \mathrm{C}$ & 60 \\
9 & spent air specific humidity & $\mathrm{g}_{\mathrm{s}}$ & $\mathrm{kg}^{\circ} / \mathrm{kg}_{\mathrm{d} . \mathrm{a}}$ & 0.041 \\
\hline
\end{tabular}

\section{Sketches/Diagrams:}

(Figure 3 shows the plant flow sheet and process diagram).
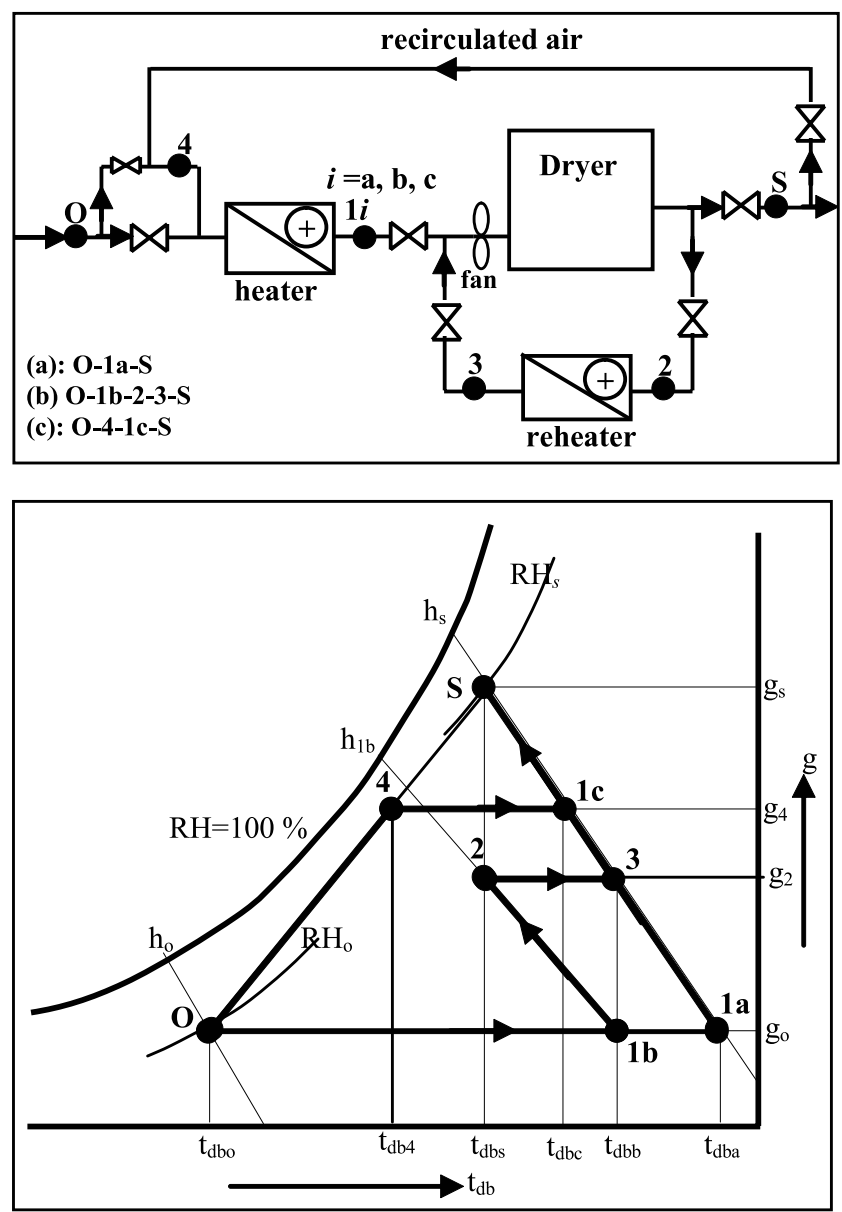

Figure 4. The convective drying plant and processes.

Data read: (psychrometric data obtained using the add-in)

\begin{tabular}{|c|c|c|c|c|c|}
\hline S/No & Quantity & Symbol & Units & Value & Value \\
\hline 1 & $\begin{array}{l}\text { outside air specific } \\
\text { enthalpy }\end{array}$ & $\mathrm{h}_{\mathrm{o}}$ & $\mathrm{kJ} / \mathrm{kg}_{\text {da }}$ & $\wp\left(\mathrm{t}_{\mathrm{dbo}}, \mathrm{g}_{\mathrm{o}}\right)$ & 46.25 \\
\hline 2 & $\begin{array}{l}\text { spent air specific } \\
\text { enthalpy }\end{array}$ & $\mathrm{h}_{\mathrm{s}}$ & $\mathrm{kJ} / \mathrm{kg}_{\mathrm{da}}$ & $\wp\left(\mathrm{t}_{\mathrm{dbs}}, \mathrm{g}_{\mathrm{s}}\right)$ & 168.13 \\
\hline 3 & $\begin{array}{l}\text { outside air relative } \\
\text { humidity }\end{array}$ & $\mathrm{RH}_{\mathrm{o}}$ & $\%$ & $\wp\left(\mathrm{t}_{\mathrm{dbo}}, \mathrm{g}_{\mathrm{o}}\right)$ & 43.33 \\
\hline 4 & $\begin{array}{l}\text { spent air relative } \\
\text { humidity }\end{array}$ & $\mathrm{RH}_{\mathrm{o}}$ & $\%$ & $\wp\left(\mathrm{t}_{\mathrm{dbs}}, \mathrm{g}_{\mathrm{s}}\right)$ & 31.09 \\
\hline 5 & $\begin{array}{l}\text { spent air wet bulb } \\
\text { temperature }\end{array}$ & $t_{\mathrm{wbs}}$ & ${ }^{\circ} \mathrm{C}$ & $\wp\left(\mathrm{t}_{\mathrm{dbs}}, \mathrm{g}_{\mathrm{s}}\right)$ & 39.8 \\
\hline 6 & $\begin{array}{l}\text { case (a) heated air } \\
\text { dry bulb tempera- } \\
\text { ture }\end{array}$ & $t_{d b a}$ & ${ }^{\circ} \mathrm{C}$ & $\wp\left(\mathrm{g}_{\mathrm{o}}, \mathrm{h}_{\mathrm{s}}\right)$ & 139.1 \\
\hline 7 & $\begin{array}{l}\text { specific humidity of } \\
\text { air in the first pro- } \\
\text { cess O-1b-2 }\end{array}$ & $\mathrm{g}_{2}$ & $\mathrm{~kg}_{\mathrm{wv}} / \mathrm{kg}_{\mathrm{da}}$ & $\wp\left(\mathrm{t}_{\mathrm{dbs}}, \mathrm{h}_{\mathrm{s}}\right)$ & 0.02528 \\
\hline 8 & $\begin{array}{l}\text { case (b) heated air } \\
\text { wet bulb tempera- } \\
\text { ture }\end{array}$ & $t_{\mathrm{wbb}}$ & ${ }^{\circ} \mathrm{C}$ & $\wp\left(\mathrm{t}_{\mathrm{dbb}}, \mathrm{g}_{\mathrm{o}}\right)$ & 34.68 \\
\hline
\end{tabular}


Computation: (Answers the question asked)

\begin{tabular}{|c|c|c|c|c|c|}
\hline S/No & Quantity & Symbol & Units & Formula & Value \\
\hline \multicolumn{6}{|l|}{ (a) } \\
\hline 1 & rate of moisture removal in the dryer & $\mathrm{m}_{\mathrm{wv}}$ & $\mathrm{kg} / \mathrm{s}$ & $\mathrm{m}_{\mathrm{wv}}=\mathrm{m}_{\mathrm{mm}}\left(\mathrm{u}_{\mathrm{in}}-\mathrm{u}_{\mathrm{fin}}\right) /\left(1-\mathrm{u}_{\mathrm{fin}}\right)$ & 0.130128 \\
\hline 2 & rise in the specific humidity of the working fluid (air) in the dryer & $\Delta \mathrm{g}_{(\mathrm{a})}$ & $\mathrm{kg}_{\mathrm{wv}} / \mathrm{kg}_{\mathrm{da}}$ & $\Delta \mathrm{g}_{(\mathrm{a})}=\mathrm{g}_{\mathrm{s}}-\mathrm{g}_{\mathrm{o}}$ & 0.0315 \\
\hline 3 & mass of dry air per kilogram of moisture evaporated & $\mathrm{x}_{(\mathrm{a})}$ & $\mathrm{kg}_{\mathrm{da}} / \mathrm{kg}_{\mathrm{wv}}$ & $\mathrm{x}_{(\mathrm{a})}=1 / \Delta \mathrm{g}_{(\mathrm{a})}$ & 31.74603 \\
\hline 4 & mass flow rate of dry outdoor air through the dryer & $\mathrm{m}_{\mathrm{o}(\mathrm{a})}$ & $\mathrm{kg}_{\mathrm{da}} / \mathrm{s}$ & $\mathrm{m}_{\mathrm{o}(\mathrm{a})}=\mathrm{m}_{\mathrm{wv}} * \mathrm{x}_{(\mathrm{a})}$ & 4.131037 \\
\hline 5 & change in the specific enthalpy of air & $\Delta \mathrm{h}_{(\mathrm{a})}$ & $\mathrm{kJ} / \mathrm{kg}_{\mathrm{da}}$ & $\Delta \mathrm{h}_{(\mathrm{a})}=\mathrm{h}_{\mathrm{s}}-\mathrm{h}_{\mathrm{o}}$ & 121.88 \\
\hline 6 & heat consumption per kilogram moisture evaporated & $\mathrm{q}_{(\mathrm{a})}$ & $\mathrm{kJ} / \mathrm{kg}_{\mathrm{wv}}$ & $\mathrm{q}_{(\mathrm{a})}=\mathrm{X}_{(\mathrm{a})} * \Delta \mathrm{h}_{(\mathrm{a})}$ & 3869.206 \\
\hline $\begin{array}{c}7 \\
(\mathbf{b})\end{array}$ & power consumption & $\mathrm{Q}_{\text {(a) }}$ & $\mathrm{kW}$ & $\mathrm{Q}_{(\mathrm{a})}=\mathrm{m}_{\mathrm{wv}} * \mathrm{q}_{(\mathrm{a})}$ & 503.4908 \\
\hline 8 & $\begin{array}{l}\text { rise in the specific humidity of the air during the first pass through the } \\
\text { dryer, process O-1b-2 }\end{array}$ & $\Delta \mathrm{g}_{\mathrm{ib} 2}$ & $\mathrm{~kg}_{\mathrm{wv}} / \mathrm{kg}_{\mathrm{da}}$ & $\Delta \mathrm{g}_{\mathrm{ib} 2}=\mathrm{g}_{2}-\mathrm{g}_{\mathrm{o}}$ & 0.01578 \\
\hline 9 & mass of dry air per kilogram of moisture evaporated in the first process & $\mathrm{x}_{(\mathrm{b})}$ & $\mathrm{kg}_{\mathrm{da}} / \mathrm{kg}_{\mathrm{wv}}$ & $\mathrm{x}_{(\mathrm{b})}=1 / \Delta \mathrm{g}_{(\mathrm{b})}$ & 63.37136 \\
\hline 10 & mass flow rate of dry outdoor air through the dryer & $\mathrm{m}_{\mathrm{o}(\mathrm{b})}$ & $\mathrm{kg}_{\mathrm{da}} / \mathrm{s}$ & $\mathrm{m}_{\mathrm{o}(\mathrm{b})}=0.5 * \mathrm{~m}_{\mathrm{wv}} * \mathrm{x}_{(\mathrm{b})}$ & 4.123183 \\
\hline 11 & change in the specific enthalpy of air & $\Delta \mathrm{h}_{(\mathrm{b})}$ & $\mathrm{kJ} / \mathrm{kg}_{\mathrm{da}}$ & $\Delta \mathrm{h}_{(\mathrm{b})}=\mathrm{h}_{\mathrm{s}}-\mathrm{h}_{\mathrm{o}}$ & 121.88 \\
\hline 12 & heat consumption per kilogram moisture evaporated & $\mathrm{q}_{(\mathrm{a})}$ & $\mathrm{kJ} / \mathrm{kg}_{\mathrm{wv}}$ & $\mathrm{q}_{(\mathrm{b})}=\mathrm{x}_{(\mathrm{b})} * \Delta \mathrm{h}_{(\mathrm{b})}$ & 7723.701 \\
\hline 13 & power consumption & $\mathrm{Q}_{(\mathrm{b})}$ & $\mathrm{kW}$ & $\mathrm{Q}_{(\mathrm{b})}=0.5 * \mathrm{~m}_{\mathrm{wv}} * \mathrm{q}_{(\mathrm{b})}$ & $\mathbf{5 0 2 . 5 3 3 6}$ \\
\hline \multicolumn{6}{|l|}{ (c) } \\
\hline 14 & specific humidity of air after mixing of the outdoor and recirculated air & $\mathrm{g}_{4}$ & $\mathrm{~kg}_{\mathrm{wv}} / \mathrm{kg}_{\mathrm{da}}$ & $\mathrm{g}_{4}=(1-\kappa) \mathrm{g}_{\mathrm{o}}+\kappa^{*} \mathrm{~g}_{\mathrm{s}}$ & 0.0347 \\
\hline 15 & rise in the specific humidity of air in the dryer & $\Delta \mathrm{g}_{(\mathrm{c})}$ & $\mathrm{kg}_{\mathrm{wv}} / \mathrm{kg}_{\mathrm{da}}$ & $\Delta \mathrm{g}_{(\mathrm{c})}=\mathrm{g}_{\mathrm{s}}-\mathrm{g}_{4}$ & 0.0063 \\
\hline 16 & mass of dry air per kilogram of moisture evaporated & $\mathrm{X}_{(\mathrm{c})}$ & $\mathrm{kg}_{\mathrm{da}} / \mathrm{kg}_{\mathrm{wv}}$ & $\mathrm{x}_{(\mathrm{c})}=1 / \Delta \mathrm{g}_{(\mathrm{c})}$ & 158.7302 \\
\hline 17 & mass flow rate of dry air through the dryer & $\mathrm{m}_{4}$ & $\mathrm{~kg}_{\mathrm{da}} / \mathrm{s}$ & $\mathrm{m}_{4}=\mathrm{m}_{\mathrm{wv}} * \mathrm{x}_{(\mathrm{c})}$ & 20.65518 \\
\hline 18 & mass flow rate of dry outdoor air through the dryer & $\mathrm{m}_{\mathrm{o}(\mathrm{c})}$ & $\mathrm{kg}_{\mathrm{da}} / \mathrm{s}$ & $\mathrm{m}_{\mathrm{o}(\mathrm{c})}=(1-\kappa) * \mathrm{~m}_{4}$ & 4.131037 \\
\hline 19 & specific enthalpy of air after mixing & $\mathrm{h}_{4}$ & $\mathrm{~kJ} / \mathrm{kg}_{\text {d.a }}$ & $\mathrm{h}_{4}=(1-\kappa) \mathrm{h}_{\mathrm{o}}+\kappa^{*} \mathrm{~h}_{\mathrm{s}}$ & 143.754 \\
\hline 20 & change in the specific enthalpy of air & $\Delta \mathrm{h}_{(\mathrm{c})}$ & $\mathrm{kJ} / \mathrm{kg}_{\mathrm{da}}$ & $\Delta \mathrm{h}_{(\mathrm{c})}=\mathrm{h}_{\mathrm{s}}-\mathrm{h}_{4}$ & 24.376 \\
\hline 21 & heat consumption per kilogram moisture evaporated & $\mathrm{q}_{(\mathrm{c})}$ & $\mathrm{kJ} / \mathrm{kg}_{\mathrm{wv}}$ & $\mathrm{q}_{(\mathrm{c})}=\mathrm{x}_{(\mathrm{c})} * \Delta \mathrm{h}_{(\mathrm{c})}$ & 3869.206 \\
\hline 22 & power consumption & $\mathrm{Q}_{(\mathrm{c})}$ & $\mathrm{kW}$ & $\mathrm{Q}_{(\mathrm{c})}=\mathrm{m}_{\mathrm{wv}} * \mathrm{q}_{(\mathrm{c})}$ & 503.4908 \\
\hline 23 & "big" wet bulb depression for (a) & $\Delta \mathrm{t}_{\mathrm{B}(\mathrm{a})}$ & $\mathrm{K}$ & $\Delta \mathrm{t}_{\mathrm{B}(\mathrm{a})}=\mathrm{t}_{\mathrm{dba}}-\mathrm{t}_{\mathrm{wbs}}$ & 99.3 \\
\hline 24 & "small" wet bulb depression for (a) & $\Delta \mathrm{t}_{\mathrm{S}(\mathrm{a})}$ & $\mathrm{K}$ & $\Delta \mathrm{t}_{\mathrm{S}(\mathrm{a})}=\mathrm{t}_{\mathrm{dbs}}-\mathrm{t}_{\mathrm{wbs}}$ & 20.2 \\
\hline 25 & drying potential (logarithmic mean temperature difference (LMTD)) for (a) & $\Delta \mathrm{t}_{\mathrm{p}(\mathrm{a})}$ & $\mathrm{K}$ & $\begin{array}{c}\Delta \mathrm{t}_{\mathrm{p}(\mathrm{a})}=\left(\Delta \mathrm{t}_{\mathrm{B}(\mathrm{a})}-\Delta \mathrm{t}_{\mathrm{S}(\mathrm{a})}\right) / \\
\left(\ln \left(\Delta \mathrm{t}_{\mathrm{B}(\mathrm{a})} / \Delta \mathrm{t}_{\mathrm{S}(\mathrm{a})}\right)\right)\end{array}$ & 49.7 \\
\hline 26 & drying potential relative to that of (a) & $\varepsilon_{\mathrm{a}(\mathrm{a})}$ & $\%$ & $\varepsilon_{\mathrm{a}(\mathrm{a})}=\left(\Delta \mathrm{t}_{\mathrm{p}(\mathrm{a})} / \Delta \mathrm{t}_{\mathrm{p}(\mathrm{a})}\right) * 100$ & 100 \\
\hline 27 & "big" wet bulb depression for (b), first pass through the dryer & $\Delta \mathrm{t} B(\mathrm{~b}), 1$ & $\mathrm{~K}$ & $\Delta \mathrm{t}_{\mathrm{B}(\mathrm{a}), 1}=\mathrm{t}_{\mathrm{dbb}}-\mathrm{t}_{\mathrm{wbb}}$ & 65.3 \\
\hline 28 & "small" wet bulb depression for (b), first pass through the dryer & $\Delta \mathrm{t}_{\mathrm{S}(\mathrm{b}), 1}$ & $\mathrm{~K}$ & $\Delta \mathrm{t}_{\mathrm{S}(\mathrm{a}), 1}=\mathrm{t}_{\mathrm{dbs}}-\mathrm{t}_{\mathrm{wbb}}$ & 25.3 \\
\hline 29 & drying potential (LMTD) for (b), first pass & $\Delta \mathrm{t}_{\mathrm{p}(\mathrm{b}), 1}$ & $\mathrm{~K}$ & $\begin{array}{l}\Delta \mathrm{t}_{\mathrm{p}(\mathrm{b}), 1}=\left(\Delta \mathrm{t}_{\mathrm{B}(\mathrm{b}), 1}-\Delta \mathrm{t}_{\mathrm{S}(\mathrm{b}), 1}\right) / \\
\quad\left(\ln \left(\Delta \mathrm{t}_{\mathrm{B}(\mathrm{b}),}, 1 / \Delta \mathrm{t}_{\mathrm{S}(\mathrm{b}), 1}\right)\right)\end{array}$ & 42.2 \\
\hline 30 & "big" wet bulb depression for (b), second pass through the dryer & $\Delta \mathrm{t}_{\mathrm{B}(\mathrm{b}), 2}$ & $\mathrm{~K}$ & $\Delta \mathrm{t}_{\mathrm{B}(\mathrm{a}), 2}=\mathrm{t}_{\mathrm{dbb}}-\mathrm{t}_{\mathrm{wbs}}$ & 60.2 \\
\hline 31 & "small" wet bulb depression for (b), second pass through the dryer & $\Delta \mathrm{t}_{\mathrm{S}(\mathrm{b}), 2}$ & $\mathrm{~K}$ & $\Delta \mathrm{t}_{\mathrm{s}(\mathrm{a}), 2}=\mathrm{t}_{\mathrm{dbs}}-\mathrm{t}_{\mathrm{wbs}}$ & 20.2 \\
\hline 32 & drying potential (LMTD) for (b), first pass & $\Delta \mathrm{t}_{\mathrm{p}(\mathrm{b}), 2}$ & $\mathrm{~K}$ & $\begin{array}{l}\Delta \mathrm{t}_{\mathrm{p}(\mathrm{b}), 2}=\left(\Delta \mathrm{t}_{\mathrm{B}(\mathrm{b}), 2}-\Delta \mathrm{t}_{\mathrm{S}(\mathrm{b}, 2)}\right) / \\
\quad\left(\ln \left(\Delta \mathrm{t}_{\mathrm{B}(\mathrm{b}), 2} / \Delta \mathrm{t}_{\mathrm{S}(\mathrm{b}), 2}\right)\right)\end{array}$ & 36.7 \\
\hline 33 & drying potential for (b) & $\Delta \mathrm{t}_{\mathrm{p}(\mathrm{b})}$ & $\mathrm{K}$ & $\Delta \mathrm{t}_{\mathrm{p}(\mathrm{b})}=0,5 *\left(\Delta \mathrm{t}_{\mathrm{p}(\mathrm{b}), 1}+\Delta \mathrm{t}_{\mathrm{p}(\mathrm{b}), 2}\right)$ & 39.5 \\
\hline 34 & drying potential relative to that of (a) & $\varepsilon_{\mathrm{a}(\mathrm{b})}$ & $\%$ & $\varepsilon_{\mathrm{a}(\mathrm{b})}=\left(\Delta \mathrm{t}_{\mathrm{p}(\mathrm{b})} / \Delta \mathrm{t}_{\mathrm{p}(\mathrm{a})}\right) * 100$ & 79.5 \\
\hline 35 & dry bulb temperature of air after the heater for (c) & $\mathrm{t}_{\mathrm{dbc}}$ & ${ }^{\circ} \mathrm{C}$ & $\wp\left(\mathrm{g}_{4}, \mathrm{~h}_{\mathrm{s}}\right)$ & 73.25 \\
\hline 36 & "big" wet bulb depression for (b), first pass through the dryer & $\Delta \mathrm{t}_{\mathrm{B}(\mathrm{c})}$ & $\mathrm{K}$ & $\Delta \mathrm{t}_{\mathrm{B}(\mathrm{c})}=\mathrm{t}_{\mathrm{dbc}}-\mathrm{t}_{\mathrm{wbs}}$ & 33.5 \\
\hline 37 & "small" wet bulb depression for (b), first pass through the dryer & $\Delta \mathrm{t}_{\mathrm{S}(\mathrm{c})}$ & $\mathrm{K}$ & $\Delta \mathrm{t}_{\mathrm{S}(\mathrm{c})}=\mathrm{t}_{\mathrm{dbs}}-\mathrm{t}_{\mathrm{wbs}}$ & 20.2 \\
\hline 38 & drying potential (LMTD) for (c) & $\Delta \mathrm{t}_{\mathrm{p}(\mathrm{c})}$ & $\mathrm{K}$ & $\begin{array}{l}\Delta \mathrm{t}_{\mathrm{p}(\mathrm{c})}=\left(\Delta \mathrm{t}_{\mathrm{B}(\mathrm{c})}-\Delta \mathrm{t}_{\mathrm{S}(\mathrm{c})}\right) / \\
\quad\left(\ln \left(\Delta \mathrm{t}_{\mathrm{B}(\mathrm{c})} / \Delta \mathrm{t}_{\mathrm{S}(\mathrm{c})}\right)\right)\end{array}$ & 26.3 \\
\hline 39 & drying potential relative to that of (c) & $\varepsilon_{\mathrm{a}(\mathrm{c})}$ & $\%$ & $\varepsilon_{\mathrm{a}(\mathrm{c})}=\left(\Delta \mathrm{t}_{\mathrm{p}(\mathrm{c})} / \Delta \mathrm{t}_{\mathrm{p}(\mathrm{a})}\right) * 100$ & 52.92 \\
\hline
\end{tabular}


The results of the solutions of the illustrative problems 1 and 2 using the add-in are in good agreement with those obtained by [10] and [12], respectively. The psychrometric data provided by the add-in are in agreement with those from the psychrometric charts for air-conditioning processes and drying processes [12] and [13], respectively. It was, however, observed that the maximum relative deviation of $4.5 \%$ occurs in the values of the specific enthalpy; but this is within an acceptable limit for most applications. The interactive nature of the MS Excel environment evokes curiosity

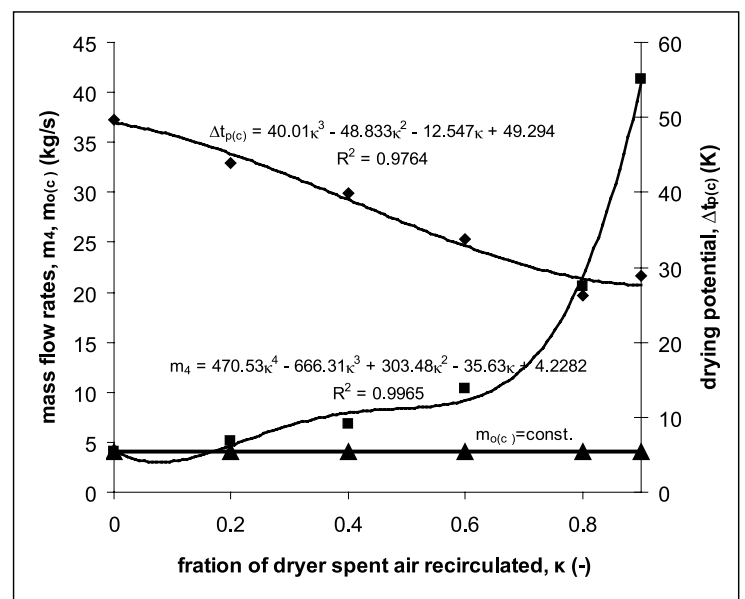

Figure 5. Variation of outdoor air flow rate $\left(\mathrm{m}_{\mathrm{oc}(\mathrm{c})}\right.$ ), mass flow rate of air through the dryer $\left(\mathrm{m}_{4}\right)$ and drying potential $\left(\Delta \mathrm{t}_{\mathrm{p}(\mathrm{c})}\right)$ as function of fraction of dryer spent air recirculated $(\kappa)$, Problem 2(c). and participation in students, and its graphic, equation-solving and curve-fitting capabilities permit the student to visualise the humid air processes and appreciate the scope and applications of thermodynamics of humid air. Comparism of process characteristics is relatively simple, and process simulation under a range of varying input parameters is always possible as in Figure 5, which shows the dependence of the outdoor dry air mass flow rate $\left(\dot{m}_{o(c)}\right)$, mass flow rate of air through the dryer $\left(\dot{m}_{4}\right)$ and drying potential $\left(\Delta t_{p(c)}\right)$ on the fraction of dryer spent air recirculated $(\kappa)$.

\section{Conclusion}

The spreadsheet add-in is provided in an easily accessible MS Excel environment to facilitate process analysis and simulation efforts of students as well as practising air-conditioning and drying engineers. Our experience has shown that students exhibit greater interest, commitment and ability in using the spreadsheet for problem solving, especially when graphical output is involved, than in the traditional approach. The tool proposed in this paper is easy to install, use and modify by engineering students in any computer driven by the MS Office. It is, therefore, strongly recommended as a teaching tool for engineering students, especially in localities with limited access to internet facilities, which may offer alternative tools online.

\section{References}

1. Beckmanand W. and Klein S. (1996), Engineering Equation Solver (EES) User manual, McGraw Hill, $\mathrm{N}$ Y.

2. Lemmon E. W., Huber M. L. and McLinden M. O. (2002), Refprop Version 7.0 User Guide, U.S NIST Department of Commerce.

3. Deane A. (2005), Developing Mathematics Creativity with Spreadsheets, J. of Korea Society of Math. Educ., Series D: R. in Math. Educ. $9 / 3$ 187201.

4. Deane A., Erich N. and Robert S. S. (2005), Mathematical Modelling and Visualization with Microsoft Excel, KAIST, Retrieved April 26th, 2006 http://www.mathnet.or.kr/kaist2005/article/arganbright.pdf.

5. Liengme V. B. (2000), A Guide to Microsoft Excel For Scientist and Engineers. Woburn, Butterworth Heinemann.

6. Schumack M. R. (1997), Teaching heat transfer using automation-related case studies with a spreadsheet analysis package, Int. J. Engineering Education, 25 177-196.

7. Lira C. T. (2000), Advanced Spreadsheet Features for Chemical Engineering Calculations, Submitted to Chem. Eng. Educ., Retrieved March 22nd, 2009 http://www.egr.edu/ lira/spreadsheats.pdf
8. Viali L. (2005), Using spreadsheets and Simulation to Enhance the Teaching of Probability and Statistics to Engineering Students, Int. Conf. on Eng. Educ., Poland, July 25-29th, (Silesian University of Technology, Gliwice).

9. Whiteman W. and Nygren K. P. (2000), Achieving the Right Balance: Properly Integrated Mathematical Software Packages into Engineering Education, J. of Enging Educ., 89/ 3 pp. 331-336.

10. Arora, C. P. (2000), Refrigeration and Air Conditioning. Tata McGrawHill, New Delhi.

11. Akpan, I. E. (2000), Analysis of Psychrometric Data for the Niger-Delta Region of Nigeria. A thesis in Mechanical Engineering for the award of M. Eng. University of Port Harcourt, Port Harcourt.

12. Pavlov, K. F et al. (1979), Examples and problems to the course of unit operations of Chemical Engineering. Mir, Moscow.

13. Eastop, T. D and McConkey, A. (1993), Applied Thermodynamics: For Engineering Technology. Fifth edition, Pearson Education, New Delhi. 